\title{
CONTENTS OF CLINICAL HEMORHEOLOGY, VOLUME 6
}

A.L. Copley and S. Witte

H. Lechner, E. Ott, N. Ossama, and F. Fazekas

Italian Acute Stroke Study Group

B.M. Coull, N.B. Beamer, and G.V.F. Seaman

E. Ott, F. Fazekas, H. Valetitsch,

E. Körner, and H. Lechner

M.R. Boisseau, M.F. Lorient Roudaut, G. Freyburger

D. Bareford, J.S. Coppock, P.C.W. Stone, P.A. Bacon and J. Stuart

A. Heinen, R. Brunner, V. Hossmann, W. Konen, K. P.oll, and Th. Wawer

E. Ernst, A. Matrai, E. Heider, and V. Will

\section{G.B. Nash and H.J. Meiselman}

G. Palareti, C. Finelli, M. Poggi, M.G. Tricarico, M. Fiacchini, P. Ricci, S. Tura, and S. Coccheri
1 Editorial

Proceedings of the Fourth European Conference on Clinical Hemorheology, Siena, Italy, 20-22 June 1985

Part II: Round Table "Cerebral Ischemia and Clinical Haemorheology", Guest Editor: H. Lechner

3 Round Table: Follow up studies of the haemorheologic profile in acute ischaemic stroke

11 Round Table: Italian acute stroke study hemodilution (I.A.S.S.-H.) Organisation and methodology

17 Round Table: Physicochemical risk factors in stroke

35 Round Table: The rationale of rheological pharmacological strategy

41 Round Table: Changes in blood filtration during acute cerebrovascular accidents

Non-Conference Communications

Papers

53 Abnormal blood rheology in Raynaud's phenomenon

61 Different types of therapy having haemorheological effects in patients with impairment of blood supply to the retina-Randomized double-blind study

81 Hemorheological and other changes after furosemide

87 Rheological properties of individual polymorphonuclear granulocytes and lymphocytes

99 Haemorheology in treated polycythaemia vera: The role of hypochromic mycrocytosis and of plasma viscosity

109 Abstract Section

I Software Survey Section 
A.L. Copley

T. Di Perri

J. Stuart

C. Ricci

A. Grossi

H. Schmid-Schönbein

S. Baar, D. Bareford, A.J. Keidan, P.C.W. Stone, and J. Stuart

V. Bartoli, B. Albanese, P.G. Manescalchi, L. Mannini, and G. Pasquini

D. Seiffge and S. Behr

A. Heinen, R. Brunner, and V. Hossmann

S. Forconi, C. Rossi, M. Guerrini,

R. Cappelli, M. Materazzi, D. Pieragalli,

S. Pecchi, A. Acciavatti, C. Galigani, T. Di Perri

J.E. Mitchell, L. Zuckerman, J.P. Vagher, D.S. Holloway, and J.A. Caprini

G. Palareti, M. Poggi, M.G. Tricarico,

F. Cavazzuti, and S. Coccheri

F.L. Liao

\section{Contents}

\section{Editorial}

Proceedings of the Fourth European Conference on Clinical Hemorheology, Siena, Italy, 20-22 June 1985

Part III

Opening Ceremony

113 Welcome Address

117 A Greeting

118 Welcome Address

120 Welcome Address

Round Table "Methods in Haemorheology II", Editor: H. Schmid-Schönbein

123 Moderator's Introductory Remarks

127 Elimination of leucocyte artefacts from erythrocyte filtration tests

137 Influence of blood storage conditions and anticoagulants on results of blood cell filtration test

151 Passage time of red blood cells in the SER; their distribution and influences of various extrinsic and intrinsic factors

165 Errata, Proceedings, Siena

Non-Conference Communications

Papers

167 Hemorheological effects of different solutions of dextran, albumin, gelatine and hydroxyethyl starch

175 Action of cigarette smoking on microcirculation. Effects on some haemorheological, haemodynamic and metabolic parameters

185 Viscoelastic coagulation studies of whole blood and plasma using a modified thrombelastograph Brief Communication

195 High Altitude Expeditions: Haemorheologic effects Letters to the Editors-in-Chief

201 Hemorheologic investigation of clotting by rotational viscometer

203 Abstract Section

I Software Survey Section 


\section{Contents}

\section{Conference Communications}

Proceedings of the Fourth European Conference on Clinical Hemorheology, Siena, Italy, 20-22 June 1985

Part IV: Round Table "Cardiovascular Diseases and Clinical Hemorheology", Guest Editor: S. Forconi

S. Coccheri and G. Palareti

\section{A.M. Ehrly}

S. Forconi, D. Pieragalli, A. Acciavatti, C. Galigani, M. Materazzi, L. Ralli,

M. Franchi F. Laghi Pasini, G.L. Messa, A. Bianciardi, M. Rigato, P. Blardi,

R. Cappelli, M. Guerrini, and T. Di Perri

E. Volger, C. Pfafferott, R. Bauersachs, U. Busch, F. Gaim, and M. Stoiber

J. Gorjão-Clara, J. Nunes, and J. Martins-Silva

E. Ernst, A. Matrai, and I. Magyarosy

C.M. Smith II, K.L. McClain, D.P. Tukey and J.H. Moller

D. Norcliffe, M.J. Brown, and M.E.L. Paterson

D.G. Waller and O.S. Roath

A.M. Ehrly
205 Interrelations between haemorheology, thrombosis and fibrinolysis

211 Diagnostic and prognostic relevance of 'extra vivum' rheological results in vascular diseases

215 Blood hyperviscosity and peripheral ischemia: The secondary hyperviscosity syndrome of ischemizing vascular diseases

229 Haemorheological aspects of myocardial ischaemia Free Communication

245 Haemorheological studies in Raynaud's syndrome

Non-Conference Communications

Papers

251 Complex environmental changes alter hemorheological, hematological and biochemical variables in volunteers

257 Relationship of cerebrovascular symptoms to blood viscosity in a patient with iron deficiency and cyanotic heart disease

265 A study of haemorheological behaviour in 150 pregnant subjects

\section{Brief Communications}

275 Nifedipine and red cell deformability in angina Letter to the Editors-in-Chief

279 Circadian Rhythm of Blood Viscosity

283 Abstract Section

I Software Survey Section 
A.L. Copley

G. Avellone and A. Strano

E. Ernst, A. Matrai, and L. Kollar

G. Pagano, G. Niort, and A. Pagani
A.M. Ehrly
E. Ott, K. Niederkorn, and F. Fazekas

P.C.W. Stone, D. Bareford, and A.J. Keidan

F. Tutinelli, A. Bisbano, G. Cremona,

G. Giovannini, V. Musumeci and G. Ciappi

M. Donner and J.F. Stoltz.

F. Liao

\section{Contents}

285 Editorial Note

Conference Communications

Proceedings of the Fourth European Conference on Clinical Hemorheology, Siena, Italy, 20-22 June 1985

Part V: Round Table "The Rationale of Rheological Pharmacological Strategy-I" Part A, Guest Editor: G. Lenti

287 Importance of adjustment of haemorheological and hiemocoagulative components in the medical treatment of arteriosclerosis obliterans of the lower limbs

297 A randomized, double blind, placebo-controlled, cross-over trial on isovolemic hemodilution in claudicants-preliminary results

303 Some problems of the pharmacologic treatment of haemorheological alterations of diabetes mellitus

Round Table "The Rationale of Rheological Pharmacological Strategy-II" Part A, Editor: T. Di Perri

325 Hemorheology and tissue oxygen supply: Relationship to pharmacological treatment

331 The implication of haemorheologic abnormalities in cerebrovascular disease

NON-CONFERENCE COMMUNICATIONS Papers

337 Rheological study of density gradient fractionated erythrocytes in diabetes and atherosclerotic vascular disease

349 Haemorheological changes in chronic respiratory failure

Report of a Meeting

357 Report on an "INSERM" technological meeting in biorheology: Techniques available for use in clinical hemorheology

Book Review

359 BLOOD VISCOSITY, HYPERVISCOSITY \& HYPERVISCOSAEMIA

361 Abstract Section

I Software Survey Section 


\author{
A.L. Copley and S. Witte \\ U. Bagge, Ä. Blixt and M. Braide
}

\section{Contents}

363 Editorial

Conference Communication

365 Fourth European Conference on Clinical Hemorheology

Round Table (Part A): Interrelationship among the blood cells and their influence on flow properties of blood

Macromodel experiments on the effect of walladhering white cells on flow resistance

Papers

A. G. Pockley, P. Davenport, F. Paul, M. Greaves and F.E. Preston

R. Cavestri, A. Pelucchi, B. Mastropasqua, R. Agosti, C. Le Grazie and E. Longhini

T.S. Kern, T.C. Romang and

R. L. Engerman

J.C. Barbenel, D.J. Barnes and G.D.O. Lowe

G.M. Glass

I. Aursnes, K. Dahl-Jørgensen and K.F. Hanssen

L. Dintenfass

J. Stuart et al

J. Dormandy, E. Ernst and A. Matrai

373 The use of high gradient magnetic separation for the preparation of leucocyte- and platelet-free red cell suspensions

381 Effects of isovolemic hemodilution in acute cerebral ischemia

395 Erythrocyte filterability in alloxan-diabetes and in experimental galactosemia

405 The prediction of high shear whole blood viscosity

413 Measurement of the suspension stability of blood in vivo in large blood vessels of the upper limb and in varicose veins

Brief Communication

429 ATP-concentrations in erythrocytes influenced by insulin levels in plasma

\section{Letter to the Editor in Chief}

435 Speculations on depletion of the red cell mass in astronauts, and on space sickness

Reports

439 Report: ICSH Expert Panel on Blood Rheology; Guidelines for measurement of blood viscosity and erythrocyte deformability

455 Report of meeting: Clinical aspects of white cell rheology, Garmisch Partenkirche, 12-13 March, 1986

\section{Abstracts}

469 Abstracts of Ninth Annual Meeting, Japanese Society of Biorheology, Ehime, Japan, 13-15 June, 1986

479 Abstracts: IV Kongress der Deutschen Gesellschaft für Klinische Hämorheologie; Minden/Westfalen (FRG) 24-25 October 1985; Rheologische Diagnostik und Therapie hämorheologischer Krankheitsbilder

I Software Survey Section 


\section{A.L. Copley and S. Witte}

D. Bareford, G.S. Lucas, P.C.W. Stone, N.M. Caldwell, R. McGonigle and J. Stuart

R. Guerciolini, F. Merante, P. Gresele, S. Grasselli, L. Susani and G.G. Nenci

M. García Rosasco, P.E. Porta and R.J. Rasia

M.E. Carr and D.A. Gabriel

C. Bernasconi, I. Ferraresi and A. Agostoni

M.C. Parker, J.W. Hynd

and J.A. Dormandy

E. Ernst, E. Schmidt-Pauly, P. Mühlig and A. Matrai

E. Longhini, R. Agosti, P. Cherubini,

A. Clivati, P. Farini and L. Marazzini

M. Stäubli, H. Rufi, P.W. Straub and J. Stuart

M. Stäubli, P.C.W. Stone, P. W. Straub and J. Stuart

C. Bucherer, C. Lacombe, J.C. Lelièvre,

A. Grimaldi and F. Bosquet

G. Artmann

S. Kobayashi, T. Hamazaki,

K. Onishi and F. Nomura

J. Mikita, G. Nash and J. Dormandy

E. Ernst

\section{Contents}

491 Editorials

Papers

501 Erythrocyte deformability in chronic renal failure

511 Effect of different plasma expanders on erythrocyte filtrability

523 Red blood cell deformability by laser diffractometry. Comparison with the filtration time method

529 Altered plasma viscosity and shear dependent gelation of a IgM cryoglobulin

541 Power law regression method for blood viscosity quantification

553 Improvement in wound healing in ischaemic limbs by perioperative normovolaemic haemodilution an animal study

561 Blood rheology in patients suffering from pressure sores

567 Haemorheology in hypertension

577 Measurement of erythrocyte deformability by radial spreading rheometry

589 Evaluation of methods for measuring erythrocyte deformability

603 Viscometric study of blood from insulin-treated diabetics with and without refinopathy correlation with biological parameters

617 A microscopic photometric method for measuring erythrocyte deformability

Brief Communications

629 Blood viscosity in fatty liver patients with obesity

635 A simple method of preparing white blood cells for filterability testing

641 Literature Survey

647 Abstract Section

649 Announcements 